\title{
Digestible and Metabolizable Energy of Various Diets for Carp and Rainbow Trout ${ }^{\dagger}$
}

\author{
Takeshi Watanabe*1 and Masahiro Ohta ${ }^{* 2}$ \\ ${ }^{* 1}$ Laboratory of Fish Nutrition, Tokyo University of Fisheries, Konan, Minato, Tokyo 108, Japan \\ ${ }^{*}$ Aquaculture Research Center, Nippon Formula Feed Mfg. Co., Ltd., Oozima, Yaizu, Shizuoka 425, Japan \\ (Received July 14, 1994)
}

\begin{abstract}
This study was conducted to determine digestible and metabolizable energy values (DE and ME) of eight practical diets and five commercial diets for carp. The proportion of DE to gross energy (GE) of the practical diets determined with large carp $(150 \sim 300 \mathrm{~g})$ was $76.3 \sim 81.6 \%$. The proportion of nonfecal energy losses to GE varied from 2.2 to $3.0 \%$, leading to ME values ranging from 3.17 to 3.54 $\mathrm{kcal} / \mathrm{g}$. The ME/DE rates were $96.1 \sim 97.2 \%$ ( $96.7 \%$ on average).

In the next experiment, amino acid imbalanced diets were used to examine the effect of feeding levels on non-fecal energy losses in rainbow trout. In the fish fed diets having a low EAA index (68.8), the proportion of non-fecal energy loss to GE increased with decrease of the GE intake, suggesting a low ME value. It is inferred that not only amino acid absorbed but also tissue proteins are deaminated to yield energy.

Seven diets, in which the EAA index ranged from 83.8 to 89.7 , were fed to carp and rainbow trout to determine the energy values of the diets. In both species the effect of the EAA index on the non-fecal energy loss was not great and the ME/DE rates were $98.5 \%$ in carp and $97.6 \%$ in rainbow trout on average.
\end{abstract}

Key words: metabolizable energy, digestible energy, non-fecal energy loss, carp, rainbow trout, amino acid imbalance

\begin{abstract}
Measurement of the energy values of diets is of great importance for practical fish culture in order to calculate the dietary energy cost for fish growth. Of the various energy values of diets, metabolizable energy is the appropriate measure of fuel availability in evaluating the potential energy utilization of formulated diets. ${ }^{1)}$ However, it is difficult to determine metabolizable energy values of diets for fish because of the need to quantify the energy losses across the gills and in urine. Many researchers have attempted to overcome these difficulties and have developed various systems and procedures. But techniques need to be developed further to obtain reliable measures of metabolizable energy before values for this parameter can be safely applied to diets. Thus digestible energy values, which are relatively easily determined, are most frequently used at present to evaluate the relative fuel values of various feedstuffs and diets. ${ }^{1,2)}$
\end{abstract}

However, metabolizable energy values are of great importance for evaluation of dietary value, especially protein quality, and of energy budget of diets for fish, in the same manner as mammals in which a constant relationship between digestible and metabolizable energy values is observed in pigs, ${ }^{3{ }^{3}}$ and metabolizable energy accounts for $96 \%$ of digestible energy. Phillips and Brockway ${ }^{4)}$ were the first to attempt to measure metabolizable energy and obtained a value of $3.9 \mathrm{kcal} / \mathrm{g}$ protein for rainbow trout using the value of $1.25 \mathrm{kcal} / \mathrm{g}$ protein for fish as non-fecal energy losses obtained in human beings.

$\mathrm{Smith}^{5}{ }^{\text {suggested that }} 4.5 \mathrm{kcal} / \mathrm{g}$ was more appropriate than $3.9 \mathrm{kcal} / \mathrm{g}$ for the metabolizable energy of protein assuming that nitrogenous wastes of rainbow trout consisted of $85 \%$ ammonia and $15 \%$ urea, and that the heats of combustion of these materials were 68.9 and $151 \mathrm{kcal} / \mathrm{mol}$, respectively. ${ }^{6}$ Elliott and Davison ${ }^{7}$ suggested $83.2 \mathrm{kcal} / \mathrm{mol}$ as a more realistic value for the heats of combustion of ammonia after reexamination. Thus different values have been reported for the metabolizable energy of protein, although metabolizable energy is greatly influenced by the composition of diets, energy value of diets, biological value of protein in diets, etc.

In a previous experiment of this series ${ }^{8)}$ the rates of endogenous nitrogen excretion through the gills and in the urine were determined under various conditions in both carp and rainbow trout, in order to measure metabolizable energy values of diets. This study was conducted to determine digestible and metabolizable energy values of carp diets containing practical ingredients and commercial diets using the rates of non-fecal energy losses obtained in the previous experiment. The effect of diets with amino acid imbalance on the values of digestible energy and metabolizable energy was also investigated with carp and rainbow trout.

\section{Materials and Methods}

\section{Experimental Diets}

The composition of the experimental diets prepared using practical ingredients is shown in Tables 1 and 2. The composition slightly varied between diets for small and large carp. Diet 1 was arranged as a low protein $(31.3 \sim 32.5 \%)$, high lipid $(11.3 \sim 14.0 \%)$ diet. Diets 2 to 7 were medium protein diets containing $35 \sim 37 \%$ crude pro-

\footnotetext{
$\uparrow$ Nutritional Energetics in Fish-II.
} 
Table 1. Composition of experimental diets prepared using practical ingredients

\begin{tabular}{|c|c|c|c|c|c|c|c|c|}
\hline \multirow{2}{*}{ Ingredients } & \multicolumn{8}{|c|}{ Diet no. } \\
\hline & 1 & 2 & 3 & 4 & 5 & 6 & 7 & 8 \\
\hline Fish meal & 25 & 25 & 15 & 25 & 15 & 25 & 25 & 30 \\
\hline Meat meal & 4 & 4 & 10 & 4 & 10 & 7 & 9 & 4 \\
\hline Soybean meal & 6 & 10 & 12 & 10 & 2 & 10 & 10 & 10 \\
\hline Defatted wheat germ meal & 0 & 5 & 0 & 0 & 0 & 0 & 0 & 5 \\
\hline Corn gluten meal & 5 & 5 & 10 & 8 & 5 & 8 & 8 & 8 \\
\hline Defatted rice bran & 9.5 & 9.5 & 9.5 & 9.5 & 9.5 & 9.5 & 9.5 & 9.5 \\
\hline Chrysalis meal & 0 & 0 & 0 & 0 & 12 & 0 & 0 & 0 \\
\hline $\mathrm{NaH}_{2} \mathrm{PO}_{4}$ & 2.5 & 2.5 & 2.5 & 2.5 & 2.5 & 2.5 & 2.5 & 2.5 \\
\hline Mineral mixture & 0.5 & 0.5 & 0.5 & 0.5 & 0.5 & 0.5 & 0.5 & 0.5 \\
\hline Vitamin mixture & 0.5 & 0.5 & 0.5 & 0.5 & 0.5 & 0.5 & 0.5 & 0.5 \\
\hline Yellow grease & 5 & 0 & 4 & 4 & 0 & 5 & 7 & 0 \\
\hline Soybean oil & $0(5)^{* 1}$ & 1 & 1 & 1 & 1 & $0(5)^{* 1}$ & $0(8)^{* 1}$ & 1 \\
\hline Sodium propionate & 0.4 & 0.4 & 0.4 & 0.4 & 0.4 & 0.4 & 0.4 & 0.4 \\
\hline $\mathrm{Cr}_{2} \mathrm{O}_{3}^{* 2}$ & 1 & 1 & 1 & 1 & 1 & 1 & 1 & 1 \\
\hline
\end{tabular}

* ( ), Diets for small carp.

$*_{2} \quad \mathrm{Cr}_{2} \mathrm{O}_{3}$ : Cellulose $=1: 1$.

Table 2. Proximate compositions of experimental diets prepared using practical ingredients and commercial diets

\begin{tabular}{|c|c|c|c|c|c|c|c|c|c|}
\hline & & \multicolumn{8}{|c|}{ Diet no. } \\
\hline & & 1 & 2 & 3 & 4 & 5 & 6 & 7 & 8 \\
\hline \multicolumn{10}{|c|}{ Experimental diets for small carp } \\
\hline Crude protein & $(\%)$ & 31.3 & 36.4 & 36.5 & 37.3 & 36.0 & 37.6 & 36.4 & 40.2 \\
\hline Crude lipid & $(\%)$ & 14.0 & 7.3 & 9.9 & 11.9 & 10.2 & 16.4 & 19.0 & 8.5 \\
\hline Gross energy & $(\mathrm{kcal} / \mathrm{g})$ & 4.65 & 4.25 & 4.47 & 4.53 & 4.47 & 4.81 & 5.00 & 4.36 \\
\hline \multicolumn{10}{|c|}{ Experimental diets for large carp } \\
\hline Crude protein & $(\%)$ & 32.5 & 35.5 & 35.4 & 36.6 & 35.7 & 37.8 & 37.9 & 39.4 \\
\hline Crude lipid & $(\%)$ & 11.3 & 7.6 & 10.9 & 12.3 & 10.6 & 12.4 & 13.6 & 8.1 \\
\hline \multirow[t]{3}{*}{ Gross energy } & (kcal/g) & 4.40 & 4.23 & 4.48 & 4.46 & 4.45 & 4.51 & 4.57 & 4.26 \\
\hline & & \multicolumn{8}{|c|}{ Commercial diets } \\
\hline & & A & $\mathbf{B}$ & $\mathrm{C}$ & D & $\mathbf{E}$ & & & \\
\hline \multicolumn{10}{|c|}{ Commercial diets for large carp } \\
\hline Crude protein & $(\%)$ & 34.0 & 34.2 & 26.2 & 35.5 & 29.2 & & & \\
\hline Crude lipid & $(\%)$ & 7.6 & 11.1 & 6.9 & 6.4 & 11.6 & & & \\
\hline Gross energy & $(\mathrm{kcal} / \mathrm{g})$ & 4.21 & 4.50 & 4.20 & 4.21 & 4.41 & & & \\
\hline
\end{tabular}

tein and $7 \sim 19 \%$ lipid. Diet 8 was a high protein diet containing about $40 \%$ crude protein. In the experiment with small carp, 5 or $8 \%$ soybean oil was added to diets 1,6 , and 7 to elevate their gross energy (GE) content. The content of crude protein in commercial carp diets (diets $\mathrm{A} \sim \mathrm{E}$ ) ranged from 26.2 to $35.5 \%$ and that of lipid $6.4 \sim 11.6 \%$, both values being lowest in diet $C$. The GE values were lower in the commercial diets. The commercial diets were prepared again by adding $0.5 \%$ chromic oxide.

The amino acid imbalanced diets containing casein and gelatin in different ratios were the same as those used in the previous experiment, ${ }^{8)}$ and their essential amino acid (EAA) index was 99.0 (diet 9), 99.7 (diet 10), 91.1 (diet 11), and 68.8 (diet 12), respectively. Diets with different EAA index were also prepared using corn gluten meal and Trula yeast in different ratios, with an EAA index ranging from 83.8 to 89.7. Each nutrient level was arranged to be almost the same among the diets as shown in their composition (Table 3).
Collection of Fecal and Urinary Nitrogenous Compounds

The apparatus used for collecting feces in this experiment is shown in Fig. 1. The feces collector was essentially the same as that used for measuring endogenous nitrogen excretion in the previous experiment, ${ }^{8)}$ but was simplified just to collect fecal materials. The glass tank measured $45 \times 30 \times 30 \mathrm{~cm}$ with a sloping bottom, and was loaded with about $200 \sim 800 \mathrm{~g}$ of fish, depending upon the purpose of the experiment. Several tanks were used for collecting feces for each diet. The velocity of the water flow was adjusted to minimize settling of feces in the trap glass column $(25 \times 4 \mathrm{~cm})$, with a water supply of $200 \sim 400 \mathrm{~m} / /$ min. The fecal materials were continuously siphoned through the trap column by the water flow.

The fish were accustomed to the dietary regime in the tank with the usual siphon system for several days before collection was started. The fish were fed to satiation three times daily, at 10:00, 12:00, and 16:30. About thirty minutes after the last meal, the bottom of the tanks was cleaned to remove feed residues and feces, and the usual 
Table 3. Composition of experimental diets with different EAA index

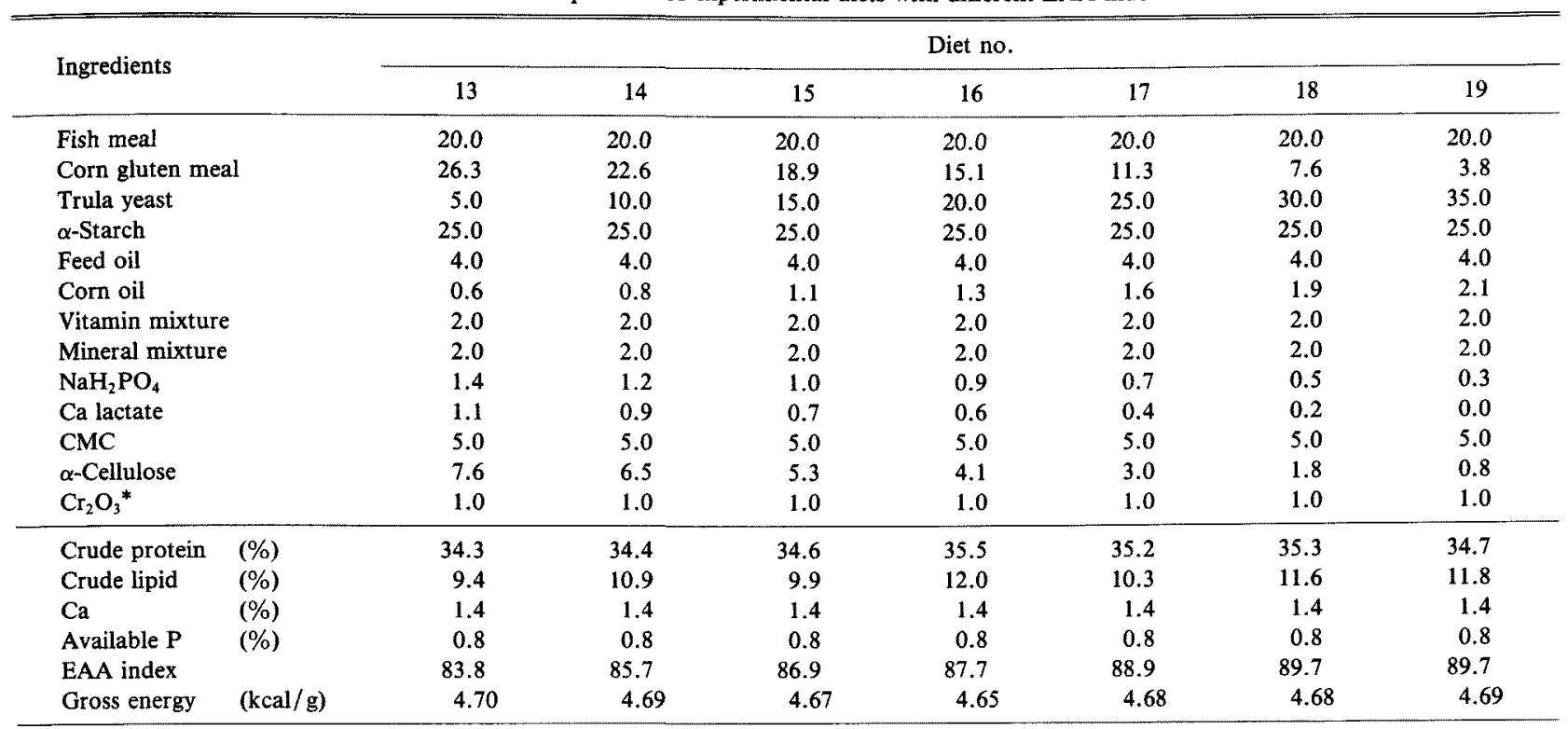

- $\mathrm{Cr}_{2} \mathrm{O}_{3}:$ Cellulose $=1: 1$.

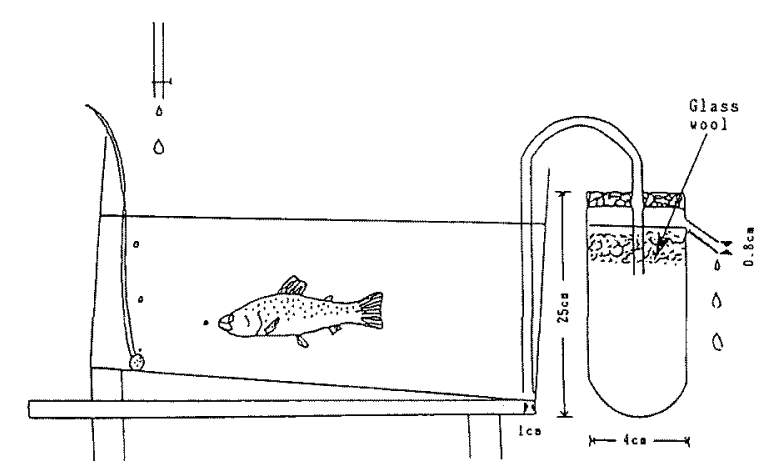

Fig. 1. The apparatus used for feces collection.

siphon column was changed to the trap column in each tank at 17:00. At 10:00 the following day the column was separated from the tank and the settled feces together with the surrounding water were gently transferred into a centrifuge tube. These feces contained no uneaten feed particles, and were considered to be a representative sample of the feces excreted during $17 \mathrm{~h}$. After separation of the trap column from the tank the fish were fed again as normal, allowing repeated sampling over one week.

The feces were centrifuged at 3,000 rpm for $10 \mathrm{~min}$ and the supernatant was discarded, then the feces were freezedried and ground for determination of chromic oxide, nutrient contents, and GE. Analytical procedures for determining nutrient contents, chromic oxide, GE, and calculation of DE values are described in previous papers. ${ }^{9,10)}$ The endogenous nitrogen excretion (ENE) rates obtained by the previous experiment, ${ }^{8)}$ together with those obtained by Ogino et $a .^{11)}$ and Ogino ${ }^{12)}$ were used to calculate the nonfecal energy lost through the gills and in the urine.

$A$ value of $5.94 \mathrm{kcal} / \mathrm{g}$ ammonia $\mathrm{N}^{7)}$ was used to calculate the ENE and non-fecal energy values.

\section{Culture Conditions}

In the feeding experiment with small carp, eight groups of 20 carp, each having a mean initial weight of $3.8 \mathrm{~g}$, were kept in $40 l$ glass tanks, and fed the diets prepared using practical ingredients (diets $1 \sim 8$ ) for 6 weeks. Each group of fish was fed on the experimental diets to satiation three times daily. The water temperature was reduced gradually from 28 to $23^{\circ} \mathrm{C}$ during the feeding period. Collection of feces started from the 3 rd week of feeding. The non-fecal nitrogen excretion through the gills and in the urine was measured on the final day of the experiment at $23^{\circ} \mathrm{C}$ according to the procedures described in a previous paper. ${ }^{8)}$

In the experiment with large carp, eight lots of 3 fish each weighing more than $150 \mathrm{~g}$ were accustomed to the test diets for 7 days, then the feces were collected for 7 days. The fish were then starved for one day for determination of body weight, and two fish were restocked into each tank for measurement of non-fecal nitrogen excretion. The feeding of the test diets was begun at 17:30 on the same day according to the same schedule described previously. ${ }^{8)}$ The fish were fed the diets at levels of $1.0 \sim 1.5 \%$ of their body weight spread over three meals daily for 4 days for the first determination, then for another 7 days for the second determination. The water temperature was kept at $24^{\circ} \mathrm{C}$.

The same experiment was also carried out using the commercial carp diets. After five commercial diets (A, B, C, D, and $E$ ) were fed to five groups of 3 carp each of body weight more than $150 \mathrm{~g}$ for 7 days, their feces were collected for 8 days. After they were starved for one day, weighed, and two of them restocked into each tank, they were fed the same diets at $1.5 \%$ spread over three meals from 17:30 on the same schedule. The non-fecal nitrogen was collected after 3 days feeding. The determination was also done with another carp weighing more than $150 \mathrm{~g}, 2$ fish each, by feeding the same diets at the same level for 6 days. The water temperature was $18 \sim 19^{\circ} \mathrm{C}$ through all the experiments.

In the experiment with the amino acid imbalanced diets 
Table 4. Digestible and metabolizable energy values of practical diets determined with small carp $\left(23^{\circ} \mathrm{C}\right)$

\begin{tabular}{|c|c|c|c|c|c|c|c|c|c|c|c|c|}
\hline $\begin{array}{c}\text { Diet } \\
\text { no. }\end{array}$ & $\begin{array}{c}\text { Average } \\
\text { body } \\
\text { weight } \\
\text { (g) }\end{array}$ & $\begin{array}{l}\text { No. } \\
\text { of } \\
\text { fish }\end{array}$ & $\begin{array}{l}\text { Feeding } \\
\text { rate } \\
\text { (\%/day) }\end{array}$ & $\begin{array}{c}\mathrm{DE}^{*_{1}} \\
\text { (kcal/g } \\
\text { diet) }\end{array}$ & $\begin{array}{c}\mathrm{DE} / \mathrm{GE}^{* 1} \\
(\%)\end{array}$ & $\begin{array}{c}\text { Non-fecal } \\
\mathrm{N}^{* 2} \\
(\mathrm{mg} / \mathrm{g} \\
\text { diet/day) }\end{array}$ & $\begin{array}{c}\text { Non-fecal } \\
\text { N loss*3 } \\
\text { (\% of } N \\
\text { intake) }\end{array}$ & $\begin{array}{c}\text { Non-fecal } \\
\text { energy*4 } \\
\text { (cal } / g \\
\text { diet) }\end{array}$ & $\begin{array}{c}\text { Non-fecal } \\
\text { energy } \\
\text { loss } \\
(\% \text { of intake })\end{array}$ & $\begin{array}{c}\mathrm{ME}^{*_{1}} \\
\text { (kcal/g } \\
\text { diet) }\end{array}$ & $\underset{(\%)}{\mathrm{ME} / \mathrm{GE}}$ & $\underset{(\%)}{\mathrm{ME} / \mathrm{DE}}$ \\
\hline \multicolumn{13}{|c|}{$\mathrm{ENE}^{* 1}=7.8$} \\
\hline 1 & 16.3 & 20 & 2.60 & 3.67 & 78.9 & 10.4 & 20.7 & 62 & 1.3 & 3.61 & 77.6 & 98.3 \\
\hline 2 & 20.7 & 20 & 3.50 & 3.27 & 76.9 & 10.9 & 18.7 & 65 & 1.5 & 3.21 & 75.4 & 98.0 \\
\hline 3 & 19.1 & 20 & 2.83 & 3.58 & 80.1 & 13.0 & 22.3 & 77 & 1.7 & 3.50 & 78.4 & 97.8 \\
\hline 4 & 20.7 & 20 & 3.57 & 3.62 & 79.9 & 12.1 & 20.3 & 72 & 1.6 & 3.55 & 78.3 & 98.0 \\
\hline 5 & 17.6 & 19 & 2.96 & 3.62 & 81.0 & 9.7 & 16.9 & 58 & 1.3 & 3.56 & 79.1 & 98.4 \\
\hline 6 & 21.1 & 20 & 3.72 & 3.80 & 79.0 & 10.0 & 16.7 & 60 & 1.2 & 3.74 & 77.8 & 98.4 \\
\hline 7 & 23.8 & 19 & 4.42 & 4.05 & 81.0 & 9.5 & 16.4 & 57 & 1.1 & 3.99 & 79.9 & 98.6 \\
\hline 8 & 15.8 & 20 & 3.21 & 3.27 & 75.0 & 11.3 & 17.6 & 67 & 1.5 & 3.20 & 74.5 & 98.0 \\
\hline \multicolumn{13}{|c|}{$\mathrm{ENE}=11.2$} \\
\hline 1 & & & & & & 9.1 & 18.1 & 54 & 1.2 & 3.62 & 77.8 & 98.5 \\
\hline 2 & & & & & & 9.9 & 13.5 & 59 & 1.4 & 3.21 & 75.6 & 98.2 \\
\hline 3 & & & & & & 11.8 & 20.2 & 70 & 1.6 & 3.51 & 78.5 & 98.0 \\
\hline 4 & & & & & & 11.2 & 18.8 & 66 & 1.5 & 3.55 & 78.5 & 98.2 \\
\hline 5 & & & & & & 8.6 & 14.9 & 51 & 1.1 & 3.57 & 79.8 & 98.6 \\
\hline 6 & & & & & & 9.1 & 15.2 & 54 & 1.1 & 3.75 & 77.9 & 98.6 \\
\hline 7 & & & & & & 8.8 & 15.1 & 52 & 1.0 & 4.00 & 80.0 & 98.7 \\
\hline 8 & & & & & & 10.2 & 15.9 & 61 & 1.4 & 3.21 & 73.6 & 98.1 \\
\hline
\end{tabular}

$*_{1}$ Abbreviations: DE, digestible energy; GE, gross energy; ME, metabolizable energy; ENE, endogenous nitrogen excretion (mg N/100g BW/day).

$* 2$ Non-fecal N: (Measured non-fecal N (mg)-ENE (mg))/diet intake (g).

*3 Non-fecal $N$ loss: (Measured non-fecal $N(m g)$-ENE $(m g)) / N$ intake $(m g) \times 100$.

*4 Non-fecal energy: Non-fecal $N(g) \times 5940$ cal.

*s Non-fecal energy loss: Non-fecal energy/GE (cal/g diet) $\times 100$.

Table 5. DE and ME values of practical diets determined with large carp

\begin{tabular}{|c|c|c|c|c|c|c|c|c|c|c|c|}
\hline $\begin{array}{l}\text { Diet } \\
\text { no. }\end{array}$ & $\begin{array}{l}\text { Total } \\
\text { body } \\
\text { weight } \\
\text { (g) }\end{array}$ & $\begin{array}{l}\text { Feeding } \\
\text { rate } \\
\text { (\%/day) }\end{array}$ & $\underset{\substack{\mathrm{kcal} / \mathrm{g} \\
\mathrm{diet})}}{\mathrm{DE}}$ & $\begin{array}{c}\mathrm{DE} / \mathrm{GE} \\
(\%)\end{array}$ & $\begin{array}{c}\text { Non-fecal } \\
N^{*} \\
(\mathrm{mg} / \mathrm{g} \\
\text { diet } / \mathrm{day})\end{array}$ & $\begin{array}{c}\text { Non-fecal } \\
N \text { loss } \\
(\% \text { of } N \\
\text { intake) }\end{array}$ & $\begin{array}{c}\text { Non-fecal } \\
\text { energy } \\
\text { (cal } / g \\
\text { diet) }\end{array}$ & $\begin{array}{c}\text { Non-fecal } \\
\text { energy } \\
\text { loss } \\
(\% \text { of intake) }\end{array}$ & $\underset{\substack{\mathrm{kcal} / \mathrm{g} \\
\mathrm{diet})}}{\mathrm{ME}}$ & $\begin{array}{c}\mathrm{ME} / \mathrm{GE} \\
(\%)\end{array}$ & $\begin{array}{c}\mathrm{ME} / \mathrm{DE} \\
(\%)\end{array}$ \\
\hline \multicolumn{12}{|c|}{ First determination } \\
\hline 1 & 523.3 & 1.04 & 3.50 & 81.6 & 20.5 & 39.4 & 122 & 2.8 & 3.44 & 78.2 & 96.6 \\
\hline 2 & 524.9 & 1.00 & 3.28 & 77.6 & 18.8 & 33.1 & 112 & 2.6 & 3.17 & 75.0 & 96.6 \\
\hline 3 & 477.9 & 1.01 & 3.49 & 78.0 & 22.3 & 39.3 & 132 & 2.9 & 3.36 & 75.1 & 96.2 \\
\hline 4 & 551.0 & 1.03 & 3.40 & 76.3 & 22.6 & 38.6 & 134 & 3.0 & 3.27 & 73.3 & 96.1 \\
\hline 5 & 489.6 & 1.02 & 3.45 & 77.6 & 16.7 & 29.3 & 99 & 2.2 & 3.35 & 75.4 & 97.1 \\
\hline 6 & 483.1 & 1.52 & 3.59 & 79.7 & 17.1 & 28.3 & 102 & 2.3 & 3.49 & 77.4 & 97.2 \\
\hline 7 & 495.0 & 1.52 & 3.65 & 79.9 & 17.4 & 28.7 & 103 & 2.3 & 3.54 & 77.6 & 97.2 \\
\hline 8 & 479.3 & 1.52 & 3.37 & 79.2 & 19.5 & 30.9 & 116 & 2.7 & 3.26 & 76.5 & 96.6 \\
\hline \multicolumn{12}{|c|}{ Second determination } \\
\hline 1 & 526.9 & 1.47 & & & 20.9 & 40.2 & 124 & 2.8 & 3.44 & 78.2 & 96.5 \\
\hline 2 & 538.9 & 1.45 & & & 19.6 & 34.4 & 116 & 2.7 & 3.17 & 74.9 & 96.5 \\
\hline 3 & 483.0 & 1.50 & & & 22.8 & 40.1 & 135 & 3.0 & 3.36 & 75.0 & 96.1 \\
\hline 4 & 558.7 & 1.47 & & & 21.4 & 36.4 & 127 & 2.9 & 3.27 & 73.4 & 96.3 \\
\hline 5 & 517.0 & 1.39 & & & 17.5 & 30.7 & 104 & 2.3 & 3.35 & 75.3 & 97.0 \\
\hline 6 & 499.3 & 1.44 & & & 18.6 & 30.7 & 110 & 2.4 & 3.48 & 77.3 & 96.9 \\
\hline 7 & 513.3 & 1.39 & & & 17.8 & 29.4 & 106 & 2.3 & 3.54 & 77.6 & 97.1 \\
\hline 8 & 483.0 & 1.49 & & & 20.6 & 32.7 & 123 & 2.9 & 3.25 & 76.3 & 96.4 \\
\hline
\end{tabular}

* The amount of ENE was calculated as $8.0 \mathrm{mg} \mathrm{N} / 100 \mathrm{~g} \mathrm{BW} /$ day $\left(24^{\circ} \mathrm{C}\right)$.

containing casein and gelatin as protein sources (diets $9 \sim 12$ ), one or two rainbow trout weighing more than $100 \mathrm{~g}$ were fed the diets at $1 \%$ spread over once or three times daily for 4 days at $7^{\circ} \mathrm{C}$ or $16^{\circ} \mathrm{C}$.

The same amino acid imbalanced diets were also used to examine the effect of feeding levels on non-fecal nitrogen excretion values. Three groups of 2 rainbow trout weighing more than $60 \mathrm{~g}$ were fed the diets once daily at three to five different feeding levels ranging from 0.5 to $1.5 \%$ of body weight for 4 days.
Diets 13 to 19 , in which the EAA index ranged from 83.8 to 89.7 , were fed to carp of more than $200 \mathrm{~g}$ and rainbow trout weighing more than $100 \mathrm{~g}$, two fish for each treatment, for 7 days to accustom the diets, then their feces were collected for another 8 days. The non-fecal nitrogen excretion was determined by feeding them the same diets three times daily at $1.5 \%$ of body weight for 4 days according to the same procedure described above. The determination was also done using about the same size of carp and rainbow trout by feeding the same diets for 6 
days at $19 \sim 20^{\circ} \mathrm{C}$ and $15^{\circ} \mathrm{C}$, respectively.

\section{Results and Discussion}

\section{Digestible and Metabolizable Energy Values of Practical Diets in Carp}

The energy values of the practical diets determined with small carp at $23^{\circ} \mathrm{C}$ are shown in Table 4 . The values were calculated using both $7.8 \mathrm{mg} \mathrm{N}$ of Ogino et al. ${ }^{(1)}$ (upper) and $11.2 \mathrm{mg} \mathrm{N} / 100 \mathrm{~g}$ body weight/day obtained by the preceding experiment ${ }^{8)}$ (lower), as ENE value. The feeding rate ranged from 2.6 to $4.4 \%$ of body weight per day between 8 diets due to feeding to satiation. The DE values of the diets were $3.27 \sim 4.05 \mathrm{kcal} / \mathrm{g}$, and the proportion of $\mathrm{DE} / \mathrm{GE}$ was $75.0 \sim 81.0 \%$. The proportion of their non-fecal energy loss was relatively lower, 1.0 to $1.7 \%$, leading to higher ME values from 3.20 to $4.00 \mathrm{kcal} / \mathrm{g}$ diet. The ME/ $\mathrm{DE}$ rates were $97.8 \sim 98.7 \%$, giving an average of $98.3 \%$, and the percentage of $\mathrm{ME}$ values in GE was $73.6 \sim 80.0 \%$ for the test diets. All the parameters were not so different between those calculated using 7.8 and $11.2 \mathrm{mg} \mathrm{N} / 100 \mathrm{~g}$ body weight/day as the ENE rate.

The results obtained with two large carp weighing about $500 \mathrm{~g}$ at $24^{\circ} \mathrm{C}$ are shown in Table 5. The DE and ME values were determined to be very close to each other, and $\mathrm{DE}$ is shown as average values in the table. Thus each parameter was found to be very close between the first and second determinations. The results obtained in diets $1 \sim 5$ suggest that the proportion of non-fecal energy loss was not affected by feeding levels between 1.0 and $1.5 \%$, and was 2.2 to $3.0 \%$ of the total energy intake. The proportion was also higher in large carp than small carp. In these experimental diets which were formulated to be close to practical carp diets, all ME values were found to be $96 \sim 97 \%$ of the DE values, similar to those of pigs in which $\mathrm{ME}$ is equal to $96 \%$ of $\mathrm{DE} .{ }^{3)}$

\section{Digestible and Metabolizable Energy of Commercial Carp Diets}

Table 6 indicates the results obtained with 5 commercial carp diets. The average DE value was $77.6 \%$ of GE, and did not vary much among the diets, while the ME values were affected by dietary protein levels. The non-fecal energy losses were quite low in the fish fed the low protein diets (diets $\mathrm{C}$ and $\mathrm{E}$ ), and agreed well with observations in rainbow trout, ${ }^{13,14)}$ carp, ${ }^{15)}$ bluegill sunfish, ${ }^{16)}$ and largemouth bass ${ }^{17}$ ) in which the proportion of non-fecal energy lost through the gills or in the urine is greatly affected by protein levels in the diet. The ME values were $3.12 \sim 3.46 \mathrm{kcal} / \mathrm{g}$ and $\mathrm{ME} / \mathrm{DE}$ ratios ranged from $97.5 \sim 99.3 \%$, significantly higher than those obtained using our experimental diets. Little information is available on the proportion of non-fecal energy loss to total energy intake. Brett and Groves ${ }^{18)}$ calculated the energy budget during processes of absorption, catabolism, and growth based on many results obtained in carnivorous fish and estimated that non-fecal energy lost is about $7 \%$ of the total energy intake. Cho ${ }^{19)}$ also demonstrated the energy budget in rainbow trout assuming that energy lost through the gills and in the urine accounts for $8 \%$ of the total energy intake.

Smith $^{5)}$ developed a special metabolic chamber to estimate ME values, however, the procedure involved considerable handling, is stressful to fish and increases nitrogen loss. The values obtained by the chamber were $0.72 \sim 0.93$ (average 0.87 ), ${ }^{1,6,20)}$ showing that a somewhat higher proportion of the combustible energy of the absorbed food components was excreted through the gills and kidney than is excreted in the urine of pigs. The proportion of $\mathrm{ME} / \mathrm{DE}$ reported by Nose $\mathrm{e}^{21}$ was $0.91 \sim 0.95$, calculated based on carcass analysis and digestibility of protein and GE. Elliott ${ }^{22,23)}$ also reported that the percentage of non-fecal energy loss was $6.0 \%$ in brown trout of $50.5 \mathrm{~g}$ at $7.1^{\circ} \mathrm{C}$ and $5.2 \%$ in those of $250 \mathrm{~g}$ at $5.6^{\circ} \mathrm{C}$ when ammonia and urea in the rearing tank were measured during $24 \sim 48 \mathrm{~h}$ after fish were starved for 3 days, followed by one day feeding. But as the ENE values were not taken into account, this might result in slightly higher values. Further studies will be necessary to develop more reliable techniques of measuring non-fecal energy losses. As stated by Cho et al. ${ }^{1)}$ until such reliable and simple methods become available, DE values should be used as a first approximation of the relative fuel values of different feed ingredients and diets.

The results of this study suggest that an average value of

Table 6. DE and ME values of commercial diets determined with large carp

\begin{tabular}{|c|c|c|c|c|c|c|c|c|c|c|c|}
\hline $\begin{array}{c}\text { Diet } \\
\text { no. }\end{array}$ & $\begin{array}{l}\text { Total } \\
\text { body } \\
\text { weight } \\
\text { (g) }\end{array}$ & $\begin{array}{l}\text { Feeding } \\
\text { rate } \\
(\% / \text { day })\end{array}$ & $\begin{array}{c}\mathrm{DE} \\
\text { (kcal/g } \\
\text { diet) }\end{array}$ & $\begin{array}{c}\mathrm{DE} / \mathrm{GE} \\
(\%)\end{array}$ & $\begin{array}{c}\text { Non-fecal } \\
\mathrm{N} \\
(\mathrm{mg} / \mathrm{g} \\
\text { diet/day) }\end{array}$ & $\begin{array}{c}\text { Non-fecal } \\
N \text { loss } \\
\text { (\% of } N \\
\text { intake) }\end{array}$ & $\begin{array}{c}\text { Non-fecal } \\
\text { energy } \\
\text { (cal/g } \\
\text { diet) }\end{array}$ & $\begin{array}{c}\text { Non-fecal } \\
\text { energy } \\
\text { loss } \\
(\% \text { of intake) }\end{array}$ & $\begin{array}{c}\mathrm{ME} \\
\text { (kcal/gt) } \\
\text { diet }\end{array}$ & $\begin{array}{c}\mathrm{ME} / \mathrm{GE} \\
(\%)\end{array}$ & $\underset{(\%)}{\mathrm{ME} / \mathrm{DE}}$ \\
\hline \multicolumn{12}{|c|}{ First determination ${ }^{* 1}$} \\
\hline A & 358.9 & 1.49 & 3.28 & 77.8 & 9.3 & 17.2 & 55 & 1.3 & 3.22 & 76.5 & 98.3 \\
\hline B & 369.6 & 1.49 & 3.52 & 78.2 & 10.8 & 19.8 & 64 & 1.4 & 3.46 & 76.8 & 98.2 \\
\hline $\mathrm{C}$ & 331.2 & 1.49 & 3.27 & 77.9 & 4.0 & 9.5 & 24 & 0.6 & 3.25 & 77.3 & 99.3 \\
\hline $\mathrm{E}$ & 350.6 & 1.49 & 3.44 & 78.0 & 6.1 & 13.1 & 36 & 0.8 & 3.40 & 77.2 & 99.0 \\
\hline \multicolumn{12}{|c|}{ Second determination ${ }^{* 2}$} \\
\hline A & 401.1 & 1.42 & & & 11.3 & 20.9 & 67 & 1.6 & 3.21 & 76.2 & 98.0 \\
\hline B & 358.2 & 1.47 & & & 12.1 & 22.2 & 72 & 1.6 & 3.45 & 76.6 & 98.0 \\
\hline $\mathrm{C}$ & 423.0 & 1.44 & & & 6.3 & 15.1 & 38 & 0.9 & 3.23 & 77.0 & 98.8 \\
\hline D & 376.7 & 1.40 & & & 13.3 & 23.5 & 79 & 1.9 & 3.12 & 74.2 & 97.5 \\
\hline $\mathbf{E}$ & 381.5 & 1.46 & & & 7.7 & 16.6 & 46 & 1.0 & 3.39 & 77.0 & 98.7 \\
\hline
\end{tabular}

*1 The amount of ENE was calculated as $7.0 \mathrm{mg} \mathrm{N} / 100 \mathrm{~g} \mathrm{BW} /$ day $\left(19^{\circ} \mathrm{C}\right)$.

$*_{2}$ The amount of ENE was calculated as $6.8 \mathrm{mg} \mathrm{N} / 100 \mathrm{~g}$ BW/day $\left(18^{\circ} \mathrm{C}\right)$. 
Table 7. Effect of the amino acid imbalanced diets on non-fecal energy losses in rainbow trout

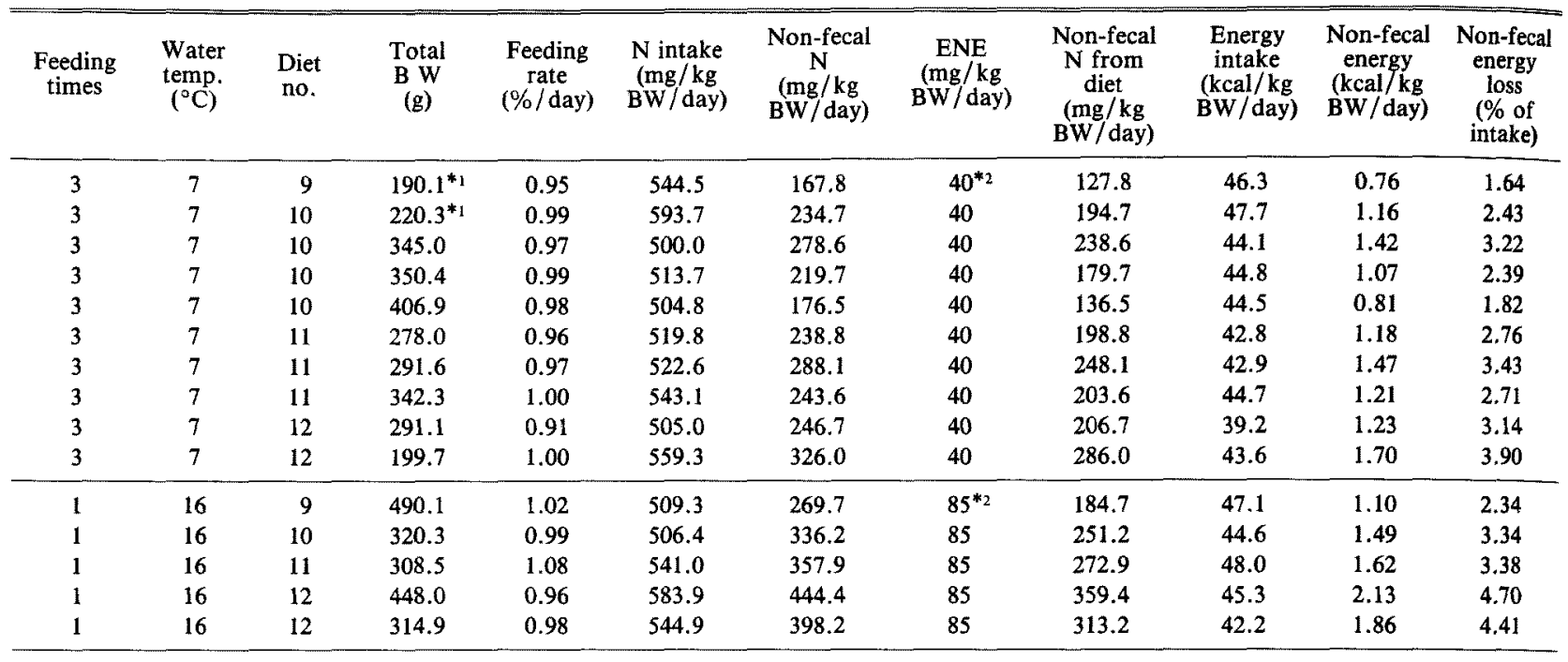

* One fish.

$*_{2}$ ENE rates were calculated as 40 and $85 \mathrm{mg} / \mathrm{kg} \mathrm{BW} /$ day at 7 and $16^{\circ} \mathrm{C}$ respectively.

Table 8. Effect of amino acid imbalanced diets and feeding levels on non-fecal energy losses in rainbow trout $\left(16^{\circ} \mathrm{C}\right)$

\begin{tabular}{|c|c|c|c|c|c|c|c|c|c|}
\hline $\begin{array}{l}\text { Diet } \\
\text { no. }\end{array}$ & $\begin{array}{l}\text { Total } \\
\text { B W } \\
(\mathrm{g})\end{array}$ & $\begin{array}{c}\text { Feeding } \\
\text { rate } \\
\text { (\%/day) }\end{array}$ & $\begin{array}{l}\mathrm{N} \text { intake } \\
(\mathrm{mg} / \mathrm{kg} \\
\mathrm{BW} / \mathrm{day})\end{array}$ & $\begin{array}{c}\text { Non-fecal N } \\
(\mathrm{mg} / \mathrm{kg} \\
\mathrm{BW} / \mathrm{day})\end{array}$ & $\begin{array}{c}\text { ENE } \\
\text { (mg/kg } \\
\text { BW/day) }\end{array}$ & $\begin{array}{c}\text { Non-fecal N } \\
\text { from diet } \\
\text { (mg/kg BW/day) }\end{array}$ & $\begin{array}{c}\text { Energy intake } \\
\text { (kcal/kg } \\
\mathrm{BW} / \text { day) }\end{array}$ & $\begin{array}{c}\text { Non-fecal } \\
\text { energy } \\
\text { (kcal/kg BW/ day) }\end{array}$ & $\begin{array}{c}\text { Non-fecal } \\
\text { energy loss } \\
\text { (\% of intake) }\end{array}$ \\
\hline 10 & 123.7 & 0.50 & 253.8 & 217.5 & 85 & 132.5 & 22.6 & 0.79 & 3.50 \\
\hline 10 & 320.3 & 0.99 & 506.4 & 336.2 & 85 & 251.2 & 44.6 & 1.49 & 3.34 \\
\hline 10 & 248.4 & 1.49 & 762.9 & 448.1 & 85 & 363.1 & 67.2 & 2.16 & 3.21 \\
\hline 11 & 209.2 & 0.54 & 271.5 & 332.7 & 85 & 247.7 & 23.9 & 1.47 & 6.15 \\
\hline 11 & 236.1 & 1.56 & 784.4 & 492.2 & 85 & 407.2 & 69.5 & 2.42 & 3.48 \\
\hline 12 & 121.6 & 0.50 & 280.4 & 333.1 & 85 & 248.1 & 22.2 & 1.47 & 6.62 \\
\hline 12 & 247.2 & 0.75 & 419.9 & 360.8 & 85 & 275.8 & 32.8 & 1.64 & 5.00 \\
\hline 12 & 314.9 & 0.98 & 544.9 & 398.2 & 85 & 313.2 & 42.2 & 1.86 & 4.41 \\
\hline 12 & 448.0 & 1.05 & 583.9 & 444.4 & 85 & 359.4 & 45.3 & 2.13 & 4.70 \\
\hline 12 & 246.0 & 1.45 & 808.1 & 552.4 & 85 & 467.4 & 63.0 & 2.78 & 4.41 \\
\hline
\end{tabular}

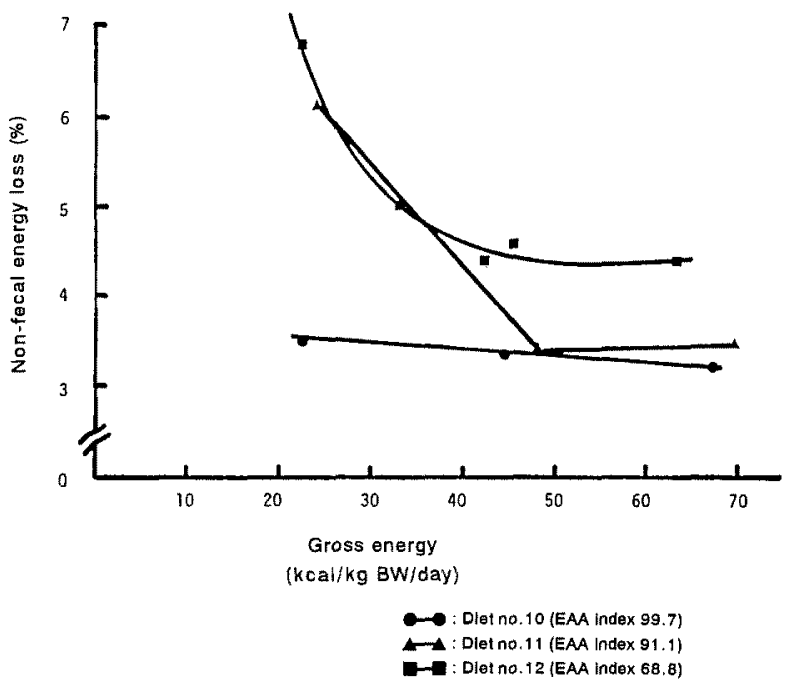

Fig. 2. Relationship between the GE intake and the proportion of nonfecal energy loss in rainbow trout fed on the amino acid imbalanced diets.
0.97 may be used as a coefficient for estimating ME values of carp diets.

Effect of Amino Acid Imbalance on DE and $M E$ Values

The effect of amino acid imbalance in diets on non-fecal energy losses is shown in Tables 7 and 8 , and Fig. 2. The diet with a low EAA index (diet 12) resulted in higher nonfecal energy loss at both 7 and $16^{\circ} \mathrm{C}$, whereas the diet with a high EAA index resulted in less excretion of non-fecal materials, as observed in the previous experiment with carp. ${ }^{8)}$ The non-fecal energy losses tended to increase with temperature as observed previously ${ }^{8}{ }^{8}$ but the value determined at $16^{\circ} \mathrm{C}$ was too small for comparison.

Figure 2 and Table 8 show the relationship between GE intake and the proportion of non-fecal energy lost through the gills and in the urine. In the fish fed on diet 10 having a high EAA index (99.7), the proportion of non-fecal energy loss remained almost constant independent of GE intake ranging from about 20 to $70 \mathrm{kcal} / \mathrm{kg}$ body weight/day. On the other hand, in the case of the diets having a low EAA index (68.8 (diet 11) or 91.1 (diet 12)), the proportion 
Digestible and Metabolizable Energy of Diets

Table 9. Effect of dietary EAA index on DE and ME values determined with carp

\begin{tabular}{|c|c|c|c|c|c|c|c|c|c|c|c|}
\hline $\begin{array}{l}\text { Diet } \\
\text { no. }\end{array}$ & $\begin{array}{l}\text { Total } \\
\text { body } \\
\text { weight } \\
\text { (g) }\end{array}$ & $\begin{array}{l}\text { Feeding } \\
\text { rate } \\
(\% / \text { day })\end{array}$ & $\begin{array}{c}\mathrm{DE} \\
\text { (kcal/g } \\
\text { diet) }\end{array}$ & $\begin{array}{c}\mathrm{DE} / \mathrm{GE} \\
(\%)\end{array}$ & $\begin{array}{c}\text { Non-fecal } \\
\mathrm{N} \\
(\mathrm{mg} / \mathrm{g} \\
\operatorname{diet} / \text { day })\end{array}$ & $\begin{array}{c}\text { Non-fecal } \\
\mathrm{N} \text { loss } \\
(\% \text { of } \mathrm{N} \\
\text { intake) }\end{array}$ & $\begin{array}{c}\text { Non-fecal } \\
\text { energy } \\
\text { (cal/g } \\
\text { diet) }\end{array}$ & $\begin{array}{c}\text { Non-fecal } \\
\text { energy } \\
\text { loss } \\
\text { (\% of intake) }\end{array}$ & $\begin{array}{c}\mathrm{ME} \\
\text { (kcal/g } \\
\text { diet) }\end{array}$ & $\begin{array}{c}\mathrm{ME} / \mathrm{GE} \\
(\%)\end{array}$ & $\begin{array}{c}\mathrm{ME} / \mathrm{DE} \\
(\%)\end{array}$ \\
\hline \multicolumn{12}{|c|}{ First determination ${ }^{* 1}$} \\
\hline 13 & 579.2 & 1.46 & 3.85 & 81.8 & 12.4 & 22.5 & 74 & 1.6 & 3.77 & 80.2 & 98.1 \\
\hline 14 & 566.2 & 1.42 & 3.82 & 81.5 & 9.1 & 16.5 & 54 & 1.2 & 3.76 & 80.3 & 98.6 \\
\hline 15 & 628.5 & 1.38 & 3.88 & 83.2 & 8.6 & 15.4 & 51 & 1.1 & 3.83 & 82.1 & 98.7 \\
\hline 17 & 601.0 & 1.45 & 3.71 & 79.3 & 8.4 & 14.9 & 50 & 1.1 & 3.66 & 78.2 & 98.7 \\
\hline 18 & 616.1 & 1.37 & 3.76 & 80.4 & 7.4 & 13.0 & 44 & 0.9 & 3.72 & 79.5 & 98.8 \\
\hline 19 & 558.8 & 1.44 & 3.80 & 81.0 & 13.6 & 24.4 & 81 & 1.7 & 3.72 & 79.3 & 97.9 \\
\hline \multicolumn{12}{|c|}{ Second determination ${ }^{* 2}$} \\
\hline 13 & 615.7 & 1.46 & & & 12.7 & 23.1 & 75 & 1.6 & 3.77 & 80.2 & 98.0 \\
\hline 14 & 585.0 & 1.39 & & & 9.1 & 16.5 & 54 & 1.2 & 3.76 & 80.3 & 98.6 \\
\hline 15 & 625.5 & 1.40 & & & 9.1 & 16.5 & 54 & 1.2 & 3.83 & 82.0 & 98.6 \\
\hline 17 & 636.3 & 1.40 & & & 8.5 & 15.0 & 50 & 1.1 & 3.66 & 78.2 & 98.7 \\
\hline 18 & 662.5 & 1.44 & & & 7.5 & 13.3 & 45 & 1.0 & 3.72 & 79.4 & 98.8 \\
\hline 19 & 631.7 & 1.42 & & & 13.3 & 23.9 & 79 & 1.7 & 3.72 & 79.3 & 97.9 \\
\hline
\end{tabular}

*1 ENE was calculated as $7.0 \mathrm{mg} \mathrm{N} / 100 \mathrm{~g} \mathrm{BW} /$ day $\left(19^{\circ} \mathrm{C}\right)$.

$* 2$ ENE was calculated as $7.2 \mathrm{mg} \mathrm{N} / 100 \mathrm{~g} \mathrm{BW} /$ day $\left(20^{\circ} \mathrm{C}\right)$.

Table 10. Effect of dietary EAA index on DE and ME values determined with rainbow trout

\begin{tabular}{|c|c|c|c|c|c|c|c|c|c|c|c|}
\hline $\begin{array}{l}\text { Diet } \\
\text { no. }\end{array}$ & $\begin{array}{l}\text { Total } \\
\text { body } \\
\text { weight } \\
(\mathrm{g})\end{array}$ & $\begin{array}{l}\text { Feeding } \\
\text { rate } \\
\text { (\%/day) }\end{array}$ & $\begin{array}{c}\mathrm{DE} \\
\text { (kcal/g } \\
\text { diet) }\end{array}$ & $\begin{array}{c}\mathrm{DE} / \mathrm{GE} \\
(\%)\end{array}$ & $\begin{array}{c}\text { Non-fecal } \\
\mathrm{N}^{* 1} \\
\left(\mathrm{~m}_{1} / \mathrm{g}\right. \\
\text { diet } / \text { day })\end{array}$ & $\begin{array}{l}\text { Non-fecal } \\
\mathrm{N} \text { loss } \\
(\% \text { of } \mathrm{N} \\
\text { intake) }\end{array}$ & $\begin{array}{l}\text { Non-fecal } \\
\text { energy } \\
\text { (cal } / g \\
\text { diet) }\end{array}$ & $\begin{array}{c}\text { Non-fecal } \\
\text { energy } \\
\text { loss } \\
\text { (\% of intake) }\end{array}$ & $\begin{array}{c}\mathrm{ME} \\
\text { (kcal/g } \\
\mathrm{diet})\end{array}$ & $\begin{array}{c}\mathrm{ME} / \mathrm{GE} \\
(\%)\end{array}$ & $\underset{(\%)}{\mathrm{ME} / \mathrm{DE}}$ \\
\hline \multicolumn{12}{|c|}{ First determination } \\
\hline 13 & 273.0 & 1.42 & 3.91 & 83.1 & 15.7 & 28.6 & 93 & 2.0 & 3.81 & 81.1 & 97.6 \\
\hline 14 & 211.2 & 1.43 & 3.82 & 81.6 & 16.4 & 29.7 & 97 & 2.1 & 3.73 & 79.5 & 97.5 \\
\hline 15 & 242.5 & 0.81 & 3.84 & 82.3 & 24.4 & 44.1 & 145 & 3.1 & 3.70 & 79.2 & 96.2 \\
\hline 17 & 268.5 & 1.46 & 3.86 & 82.6 & 13.9 & 24.7 & 83 & 1.8 & 3.78 & 80.8 & 97.9 \\
\hline 18 & 276.3 & 1.43 & 3.90 & 83.5 & 9.0 & 16.0 & 54 & 1.2 & 3.85 & 82.3 & 98.6 \\
\hline 19 & 228.6 & 1.43 & 3.70 & 78.8 & 11.6 & 20.9 & 69 & 1.5 & 3.63 & 77.3 & 98.1 \\
\hline \multicolumn{12}{|c|}{ Second determination ${ }^{*_{2}}$} \\
\hline 13 & 159.9 & 1.37 & & & 18.3 & 33.3 & 109 & 2.3 & 3.80 & 80.8 & 97.2 \\
\hline 14 & 133.4 & 1.33 & & & 16.1 & 29.3 & 96 & 2.0 & 3.73 & 79.6 & 97.5 \\
\hline 15 & 110.3 & 1.40 & & & 18.8 & 33.9 & 111 & 2.4 & 3.73 & 79.9 & 97.1 \\
\hline 17 & 114.3 & 1.37 & & & 12.9 & 22.8 & 76 & 1.6 & 3.79 & 81.0 & 98.0 \\
\hline 18 & 117.7 & 1.35 & & & 13.6 & 24.2 & 81 & 1.7 & 3.82 & 81.8 & 97.9 \\
\hline 19 & 108.6 & 1.36 & & & 11.8 & 21.3 & 70 & 1.5 & 3.63 & 77.3 & 98.1 \\
\hline
\end{tabular}

*1 ENE was calculated as $7.5 \mathrm{mg} \mathrm{N} / 100 \mathrm{~g} \mathrm{BW} /$ day $\left(15^{\circ} \mathrm{C}\right)$.

$*_{2}$ One fish was used.

increased with decrease of GE intake. This may suggest that not only amino acid absorbed but also tissue proteins are deaminated to yield energy to counterbalance the energy requirement in the case of low energy intake. Thus the non-fecal energy loss was found to be greatly influenced by the total energy intake in terms of $\mathrm{DE}$ as already observed by many researchers. ${ }^{15,16,22)}$

The results obtained in carp and rainbow trout with the diets having different EAA index, ranging from 83.8 to 89.7, are shown in Tables 9 and 10. In both species no clear effect of the EAA index on the non-fecal nitrogen excretion was observed, since the EAA value did not differ greatly among the diets. The proportion of ME to the total energy of diets was $78 \sim 84 \%$ in carp and $77 \sim 83 \%$ in rainbow trout.

\section{References}

1) C. Y. Cho, S. J. Slinger, and H. S. Bayley: Bioenergetics of salmonid fishes: Energy intake, expenditure and productivity. Comp. Biochem. Physiol., 73B, 25-41 (1982).

2) M. Jobling: A short review and critique of methodology used in fish growth and nutrition studies. J. Fish Biol., 23, 685-703 (1983).

3) NRC (National Research Council): Nutrient requirements of swine, National Academy Press, Washington D.C., 1988, p. 2.

4) A. M. Phillips, Jr. and D. R. Brockway: Dietary calories and the production of trout in hatcheries. Prog. Fish-Cult., 21, 3-16 (1959).

5) R. R. Smith: A method for measuring digestibility and metabolizable energy of fish feeds. Prog. Fish-Cult., 33, 132-134 (1971).

6) R. R. Smith, M. C. Peterson, and A. C. Allred: Effect of leaching on apparent digestion coefficients of feedstuffs for salmonids. Prog. Fish-Cult., 42, 195-199 (1980). 
7) J. M. Elliott and W. Davison: Energy equivalents of oxygen consumption in animal energetics. Oecologia., 19, 195-201 (1975).

8) T. Watanabe and M. Ohta: Endogenous nitrogen excretion and non-fecal energy losses in carp and rainbow trout. Fisheries Science, 61, 53-60 (1995).

9) T. Takeuchi, K.-S. Jeong, and T. Watanabe: Availability of extruded carbohydrate ingredients to rainbow trout Oncorhynchus mykiss and carp Cyprinus carpio. Nippon Suisan Gakkaishi, 56, 1839-1845 (1990).

10) T. Takeuchi, T. Watanabe, and C. Ogino: Availability of carbohydrate and lipid as dietary energy sources for carp. Nippon Suisan Gakkaishi, 45, 977-982 (1979).

11) C. Ogino, J. Kakino, and M. S. Chen: Protein nutrition in fish-II. Determination of metabolic fecal nitrogen and endogenous nitrogen excretions of carp. Nippon Suisan Gakkaishi, 39, 519-523 (1973).

12) C. Ogino: Tanpakushitu, Gyorui no eiyouso ni taisuru youkyuu, in "Gyorui no Eiyou to Shiryou" (ed. by C. Ogino), Ist ed., Koseisha-Kosei Kaku, Tokyo, 1980, pp. 111-139 (in Japanese).

13) J. Rychly: Nitrogen balance in trout II. Nitrogen excretion and retention after feeding diets with varying protein and carbohydrate levels. Aquaculture, 20, 343-350 (1980).

14) F. W. H. Beamish and E. Thomas: Effects of dietary protein and lipid on nitrogen losses in rainbow trout, Salmo gairdneri. Aquaculture, 41, 359-371 (1984).

15) S. J. Kaushik and K. Dabrowski: Nitrogen and energy utilization in juvenile carp (Cyprinus carpio) fed casein, amino acids or a prot- ein-free diet. Reprod. Nutr. Develop., 23, 741-754 (1983).

16) J. Savitz: Nitrogen excretion and protein consumption of the bluegill sunfish (Lepomis macrochirus). J. Fish. Res. Bd. Canada, 28, 449-451 (1971).

17) J. Savitz, E. Albanese, M. J. Evinger, and P. Kolasinski: Effect of ration level on nitrogen excretion, nitrogen retention and efficiency of nitrogen utilization for growth in largemouth bass (Micropterus salmoides). J. Fish Biol., 11, 185-192 (1977).

18) J. R. Brett and T. D. D. Groves: Physiological energetics, in "Fish Physiology" (ed. by W. S. Hoar, D. J. Randall, and J. R. Brett), Vol. 8, Academic press, New York, 1979, pp. 279-352.

19) C. Y. Cho: Effects of dietary protein and lipid levels on energy metabolism of rainbow trout (Salmo gairdneri), Proc. of the 9th International Symp. on Energy Metabolism of Farm Animals, Lillehammer. No. 29, 1982, pp. 176-179.

20) NRC (National Research Council): Nutrient requirements of coldwater fishes, National Academy Press, Washington D.C., 1981, pp. 37-41.

21) T. Nose: Energy metabolism, in "Metabolism in Fish" (ed. by F. Nagayama), Koseisha-Kosei Kaku, Tokyo, 1983, p. 111 (in Japanese).

22) J. M. Elliott: Energy losses in the waste products of brown trout (Salmo trutta). J. Anim. Ecol., 45, 561-580 (1976).

23) J. M. Elliott: Nitrogen balance in trout II. Nitrogen excretion and retention after feeding diets with varying protein and carbohydrate levels. J. Anim. Ecol., 45, 923-948 (1976). 